\title{
Children and Adolescents with Severe Acute Behavioural Disturbance in the Emergency Department
}

\section{Authors:}

Anna Carison MANP 1

Franz E Babl MD 1-3

Ashley Hill RN 3

Sinead M O'Donnell MD 1,3

1 Emergency Department Royal Children's Hospital

2 University of Melbourne

3 Department of clinical sciences, Murdoch Children's Research Institute

\section{Correspondence to:}

Prof Franz Babl

The Royal Children's Hospital

50 Flemington Road

Parkville, Victoria 3052 Australia

Franz.Babl@rch.org.au

Short Title:

Acute behavioural disturbance

\section{Word count:}

2702

Funding

Unfunded

Financial disclosure

Nil

\section{Conflicts of interest:}

None

\section{Abbreviations}

$A B D$ - acute behavioural disturbance

ATS - Australasian triage scale

This is the author manuscript accepted for publication and has undergone full peer review but has not been through the copyediting, typesetting, pagination and proofreading process, which may lead to differences between this version and the Version of Record. Please cite this article as doi: $10.1111 / 1742-6723.13515$

This article is protected by copyright. All rights reserved. 
ED - emergency department

EMR - electronic medical record

LOS - length of stay

$\mathrm{MH}$ - mental health

PED - paediatric emergency department

\section{Table of contents summary}

Severe acute behavioural disturbance in children and adolescents in the emergency department, regardless of underlying cause, can be a major management challenge.

\section{What is already known}

- Mental health presentations to the emergency department are increasing in children and adolescents.

- Little is known about patients with severe acute behavioural disturbance, the most severe end of these presentations.

- Interventions used in a crisis team response or "Code Grey" are currently not evidence based.

\section{What this study adds}

- Children and adolescents with severe acute behavioural disturbance have increased acuity, length of stay and hospital admissions compared with those presenting with other mental health problems, and often require physical or chemical restraint.

- This cohort are often repeat presenters for whom development of anticipatory management plans may be suitable.

\section{Contributors statement page}

AC, SMOD and AH conceived the study, obtained ethics approval, extracted and analysed the data and wrote the first draft of the paper.

FEB assisted with the design of the study protocol, obtained ethics approval and revised the draft.

All authors approved the final draft for submission.

This article is protected by copyright. All rights reserved. 


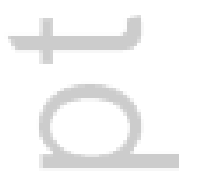

This article is protected by copyright. All rights reserved. 


\section{ABSTRACT}

\section{OBJECTIVE}

Mental health $(\mathrm{MH})$ presentations to emergency departments (EDs) are increasing in children and adolescents. Little is known about patients with severe acute behavioural disturbance $(A B D)$. We set out to describe patients with $A B D$ severe enough to trigger an acute crisis team response in ED (termed "Code Grey") and how they differ from other MH patients.

\section{METHODS}

Retrospective electronic medical record review (EMR) of all ED patients with $\mathrm{MH}$ discharge codes at a tertiary children's hospital. We assessed the epidemiology and management of patients who triggered acute crisis team interventions (Code Grey) as proxy for severe ABD. We calculated the odds ratios (ORs with $95 \%$ confidence intervals $(\mathrm{CI})$ ) of key demographic factors compared to other $\mathrm{MH}$ patients.

\section{RESULTS}

During 2018 there were 85,347 ED presentations of which 1695 (2.0\%) were related to $\mathrm{MH}$ diagnoses; $84 \mathrm{MH}$ patients had $141 \mathrm{MH}$ presenations triggering 204 Code Greys (26 patients triggered 59\% of Code Greys). These patients had higher triage acuity (OR 12.6 (8.3 to 19.0)), stayed longer in ED (> 12 hrs OR 8.2 (5.1 to 13.1)) and were more likely to be admitted (OR 2.0 (1.4 to 3.0)) compared with non-Code Grey MH presentations. Patients were physically (19.2\%), mechanically $(31.9 \%)$ or chemically restrained (37.6\%). Eight different medication approaches were used as either a single agent or a combination of oral and/or intramuscular agents.

\section{CONCLUSIONS}

This article is protected by copyright. All rights reserved. 
Children and adolescents with severe $\mathrm{ABD}$ differ from other $\mathrm{MH}$ presentations and often require physical or chemical restraint. Anticipatory management plans may be suitable for repeat presenters.

\section{KEY WORDS}

Acute behavioural disturbance

Mental health presentations

Paediatrics

Emergency

Restraint

This article is protected by copyright. All rights reserved. 


\section{INTRODUCTION}

Mental health $(\mathrm{MH})$ presentations to paediatric emergency departments (PEDs) in Australia have significantly increased in recent years, in comparison to both paediatric physical health presentations ${ }^{1}$ and adult $\mathrm{MH}$ presentations ${ }^{2}$. $\mathrm{MH}$ presentations are more likely to arrive out of business hours, be triaged as urgent, stay longer in ED and be admitted to hospital ${ }^{1,2}$. Similar increases in presentations and length of stay (LOS) are reported in the USA $^{3}$.

In adult EDs there has been considerable focus on the increasing number of patients with severe $A B D$ in particular; they often remain in $E D$ for long durations and require considerable resources to safely manage ${ }^{4}$. Aggressive and agitated patients often require a coordinated staff response to safely manage these behaviours and minimise risk to the patient, other patients and staff. In Victoria, this response is known as "Code Grey". In adult EDs, patients with $A B D$ requiring a Code grey are more likely to be male, drug and/or alcohol affected, have an underlying mental health illness ${ }^{4-5}$, arrive with the police ${ }^{4}$, be triaged as urgent and be admitted to hospital, compared with non-MH presentations ${ }^{5}$.

Severe ABD, Code Grey response and the use of restrictive intervention has not been well studied in children and adolescents in $\mathrm{ED}^{6}$. Considering the reports of increasing paediatric $\mathrm{MH}$ presentations $\mathrm{s}^{1,2}$ and particular concerns about the severe end of the spectrum of these presentations we set out to assess children and adolescents presenting to a tertiary children's hospital ED with ABD. We aim to describe a cohort of patients with ABD

This article is protected by copyright. All rights reserved. 
severe enough to trigger an acute crisis team response in ED (Code Grey) and how they differ from other MH patients.

\section{METHODS}

\section{Design and Setting}

We conducted a retrospective EMR review of all ED patients with $\mathrm{MH}$ discharge codes at the Royal Children's Hospital $(\mathrm{RCH})$ in Melbourne, Australia. We then assessed the epidemiology and management of patients who triggered acute crisis team interventions (Code Grey) as a proxy indicator for severe ABD.

$\mathrm{RCH}$ is a large tertiary children's hospital with an annual census of 85,347 children (2018) and is a designated MH facility under Victorian Mental Health Act regulation ${ }^{7,8}$, servicing a population of over 6 million people ${ }^{9}$. The $\mathrm{MH}$ service consists of the ED, a 16-bed adolescent inpatient unit and accessible outpatient services for children up to the age of 18. The study was approved by the Human Research and Ethics Committee (HREC) at RCH (HREC QA/51710/RCHM-2019).

\section{Code Grey}

"Code grey" is an emergency alert used at RCH to elicit a rapid response to a situation of anticipated danger or risk by a person towards themselves, other patients, staff members, visitors or property. This type of response may involve verbal de-escalation or restraint of a potentially aggressive person by an emergency response team trained in the management of aggression ${ }^{10,11}$. Management of $A B D$ often involves chemical sedation,

This article is protected by copyright. All rights reserved. 
which is guided by a stepwise approach to pharmacological management described in the $\mathrm{RCH}$ clinical practice guideline on ABD: Code Grey ${ }^{11}$. In ED, the Code Grey team consists of a senior emergency physician, the ED nurse and/or associate unit manager, three ward nurses from outside the ED, two security staff and a member of the hospital administrative executive $^{11}$. Code grey events are electronically logged on the EMR and separate Code Grey specific records are held by the hospital Code Grey co-ordinator; both allow case identification.

\section{Study procedure}

A list of $66 \mathrm{MH}$ related ICD 10 diagnostic codes were used to identify $\mathrm{MH}$ presentations to ED. This list included all psychiatric diagnoses available to treating staff and other diagnoses not specifically psychiatric but often associated with a $\mathrm{MH}$ presentation (ingested foreign body, forearm laceration and hallucination). The ICD 10 diagnostic codes were used to identify patients for inclusion; EMRs of all identified MH presentations were manually assessed to confirm $\mathrm{MH}$ related presentations, exclude non- $\mathrm{MH}$ presentations, assess the $\mathrm{ED}$ and $\mathrm{MH}$ clinician diagnosis and any underlying $\mathrm{MH}$ or medical diagnosis reported in the medical record. The total $\mathrm{MH}$ population elicited by the ICD 10 code search was cross-referenced with the mandatory "Code Grey" records to identify a subset of presentations who required at least one Code Grey response while in ED. For identified patients we extracted relevant demographic, diagnostic, management and follow up data, using an a priori developed coding dictionary. Data extractors were trained and intermittently audited ${ }^{12}$.

This article is protected by copyright. All rights reserved. 
Inclusion criteria:

- All $\mathrm{MH}$ presentations aged 7 to $<18$ years presenting to $\mathrm{ED}$, who had a $\mathrm{MH}$ diagnosis assigned by the ED and / or MH clinician

Exclusion criteria:

- Children under 7 and $\geq 18$ years of age

- Presentations with a diagnosis of ingested foreign body or forearm laceration where there was no $\mathrm{MH}$ issue

\section{Definitions}

- ED triage urgency was defined using the national Australian triage scale (ATS) ${ }^{13}$.

- Restrictive interventions were assessed as regulated under the Victorian Mental Health Act $2014^{8}$ and involved use of bodily restraint and seclusion. A restrictive intervention under the Act may only be used after all reasonable and less restrictive options and have been attempted or considered or are unsuitable in the circumstances. They included:

o Bodily restraint

o Physical restraint

o Mechanical restraint

o Chemical restraint

o Sedation

o Seclusion

This article is protected by copyright. All rights reserved. 
- Section 351 of the Victorian Mental Health $\mathrm{Act}^{8}$ is the apprehension of a person by police if the person appears to have a mental illness and needs to be apprehended to prevent serious and imminent harm to the person or another person, and subsequent transport to a medical or mental health practitioner or a public hospital for examination.

\section{Analysis}

Data were entered into an Excel database (Microsoft, Seattle, WA, USA) and analysed using Stata 14 (Stata Corp, College Station, Tx, USA). We reported LOS related variables for all $\mathrm{MH}$ presentations and Code Grey related presentations. We reported demographic data for all $\mathrm{MH}$ and Code Grey presentations using frequencies and percentages with $95 \%$ confidence intervals $(\mathrm{Cls})$, and additional presentation related variables for the subset of Code Grey presentations. Our primary analysis was focused on identifying the differences between Code Grey and non-Code Grey MH presentations using odds ratios (ORs) of key demographic factors.

\section{RESULTS}

During 2018 there were 85,347 ED presentations of which 1695 (2.0\% of total ED presentations, median age 14, IQR 13-16) were related to $\mathrm{MH}$ diagnoses (Figure 1). In the corresponding period, there were 292 Code Grey events of which 204 (69.8\%) were associated with 141 ED MH presentations. The 88 (30.1\%) Code Grey events excluded from

This article is protected by copyright. All rights reserved. 
analysis were associated with accompanying adults (parents or visitors), children under 7 years of age and adolescents presenting with acute behavioural disturbance due to drug or alcohol intoxication ( $n=12,4.1 \%$ of total Code Grey group) with no $\mathrm{MH}$ diagnosis. A total of 84 patients accounted for the $141 \mathrm{MH}$ presentations requiring at least one Code Grey response. Of these 84 patients, 26 patients had multiple presentations and accounted for more than half of the total MH presentations ( $n=83,58.9 \%$ ) (Figure 1 ). There was more suicidality in this smaller cohort of 26 patients ( $46 \%$ presenting with suicidal ideation) compared with the total re-presenting group ( $n=84,26 \%$ presenting with suicidal ideation).

$\mathrm{MH}$ presentations requiring a Code Grey response were more likely to be female (74.5\%, OR 1.5 (1.0 to 2.2), median age 15, IQR 12-16) compared with non-Code Grey $\mathrm{MH}$ presentations (66.1\%, median age 15, IQR 13-16) (Table 1). The Code Grey group were of higher acuity (37.6\% triage category 1 \& 2 OR 12.6 (8.3 to 19.0$)$ ), stayed longer in ED (24.1\% $>12$ hrs OR 8.2 (5.1 to 13.1)) and were more likely to be admitted (29.1\% OR 2.0 (1.4 to 3.0)) compared with the non-Code Grey MH presentations (acuity $4.6 \%$ triage category $1 \&$ 2; LOS 3.7\% > 12 hrs; admission rate $16.9 \%$ ) (Table 1).

Over half of the Code Grey group were brought to ED with police (51.1\%) and over a third (38.3\%) were under section 351 of the Victorian mental health act (Table 2). The Code Grey group predominantly arrived outside of business hours (60.3\%), were discharged home with a parent(s) (58.9\%) who was also their legal guardian (68.8\%), and with community psychiatric follow up organised (73.8\%) (Table 1 and 2 ). The majority (92.2\%) had a previous $\mathrm{MH}$ presentation to ED or community psychiatric involvement, and a psychiatric diagnosis 
which was made either prior to ED presentation or subsequently in follow up $(95.7 \%$ of presentations) (Table 2).

The majority of Code Grey events were called outside of business hours (62.4\%) and within 2 hours of arrival to ED (73.8\%) (Table 3). Typically, one Code Grey event was required per presentation (69.5\%), hands on restraint (either physical or mechanical) was used in $51.1 \%$ of cases, chemical restraint in $36.9 \%$ and seclusion in $30.5 \%$ (Table 3 ). There was one documented incident of a staff member being injured during a Code Grey event in ED.

For a total of 53 presentations psychotropic medications were administered during the Code Grey (37.6\%); IM medication was given in 22 presentations and oral medication given in 31. A total of 79 medication doses were dispensed during the 53 Code Greys; $30.2 \%$ received two and $18.9 \%$ received three or more medications, with up to 4 oral and 5 IM injections administered. Of the IM medications given, the most frequently administered was droperidol IM, followed by olanzapine IM and midazolam IM (Table 3). The most common orally administered medication was olanzapine PO followed by diazepam PO (Table 3). There were no adverse effects documented for any medications administered in ED.

Of the Code Grey cohort, the most common diagnosis made by an ED or MH clinician was acute behavioural disturbance $(41.1 \%)$, followed by suicidal ideation ( $27.7 \%)$ (Table 4 ). Where there was a pre-existing $\mathrm{MH}$ diagnosis, the most frequent was autism spectrum disorder (ASD) (17.0\%), chronic suicidality (14.2\%) or depression (11.4\%) (Table 5, supplementary data). Those with no pre-existing $\mathrm{MH}$ diagnosis were either not seen by a

This article is protected by copyright. All rights reserved. 
$\mathrm{MH}$ clinician during that presentation, or were yet to receive a formal $\mathrm{MH}$ diagnosis. For the subset of 26 patients with repeat presentations who accounted for over half of the total $\mathrm{MH}$ presentations, the predominant pre-existing $\mathrm{MH}$ diagnoses were chronic suicidality (23.1\%), ASD (15.4\%), borderline personality disorder (11.5\%) and depression (11.5\%).

There was a proportionately higher rate $(11.5 \%)$ of Code Grey activation in the younger age group (7-12 years) compared with the older group (13-17 years, 7.3\%, OR 1.6 (1.1 to 2.4)) and the younger group were significantly more likely to be diagnosed with acute behavioural disturbance ( $72.3 \%$ in younger group, $23.4 \%$ in older group, OR 8.6 (3.9 to 19.0)).

\section{DISCUSSION}

Our study has identified children and adolescents presenting to ED with $\mathrm{MH}$ issues who triggered a Code Grey response due to severe acute behavioural disturbance. These patients differ from other $\mathrm{MH}$ presentations by having a higher triage acuity, staying longer in ED and having a higher admission rate. A high proportion of children were physically, mechanically and/or chemically restrained. Our data identify a particularly vulnerable group of patients with repeat Code Grey presentations, where just 26 patients account for the majority of Code Grey responses; typically these patients are 15-year-old girls expressing suicidality with a psychiatric history and are brought restrained by Police under section 351 of the Victorian Mental Health Act. Although the average age of patients requiring a Code Grey response was 15 years, we found that the younger age group (7-12 year olds) had

This article is protected by copyright. All rights reserved. 
relatively more frequent acute severe behavioural disturbance presentations requiring Code Grey activation during their ED presentations than the older group (13-17 year olds). Our finding of a smaller, high intensity cohort of frequent presenters provides a unique opportunity to better understand and prepare for this patient group, with a focus on improving pre-hospital and ED care. Reasons for frequent mechanical restraint in children and adolescents likely differ from adults but are not well researched ${ }^{14}$. The $\mathrm{RCH}$ utilises the statewide clinical practice guideline on acute behavioural disturbance ${ }^{11}$ and the local restrictive interventions policy and procedure guideline ${ }^{15}$. It is recommended that mechanical restraints are only used as a last resort, with a coordinated, trained, swift fiveperson Code Grey team approach and with accompanying sedation. There are specific indications for restraint and the need for restraint is reviewed on an ongoing basis by the Code Grey team leader. The mechanical restraint is removed once control is gained and in a stepwise fashion (one limb at a time). Focused interventions to prevent and reduce the use of restrictive intervention should take into account specific patient characteristics and may be achievable through tailored management plans. Joint crisis plans (JCP) used in adult $\mathrm{MH}$ settings are advanced agreements between patients and clinicians to document treatment preferences for future crisis presentations and have been shown to reduce admission and treatment in $\mathrm{MH}$ services ${ }^{16}$. Anticipatory crisis plans could be developed in the paediatric ED setting for all frequent presenters that are easily accessible in ED and prior to arrival by prehospital services and may similarly reduce restrictive interventions and admission.

This article is protected by copyright. All rights reserved. 
The Victorian Police, Ambulance and Clinical Early Response (PACER) service is a mobile adult emergency $\mathrm{MH}$ response that aims to resolve $\mathrm{MH}$ crisis in the community; since its introduction in 2007, this model has demonstrated quicker access to $\mathrm{MH}$ assessment, improved information sharing between agencies and decreased referrals and transport to $\mathrm{EDs}^{17}$. If transport is required, several Victorian adult EDs incorporate an on-site $\mathrm{MH}$ and $\mathrm{AOD}$ (alcohol and other drugs) hub ${ }^{18}$, which has been shown to decrease use of restrictive interventions and LOS in $E D^{19}$.

There is currently no paediatric equivalent mobile or on-site service. Our data allow only a limited comparison with adult Code Grey data due to different populations and exclusions. Whereas adults requiring Code Grey response tend to be male and present drug or alcohol affected, often with a $\mathrm{MH}$ background ${ }^{4,5}$, children and adolescents were predominantly female teenagers with a primary $\mathrm{MH}$ complaint. The broad similarity across all age groups is a pre-existing $\mathrm{MH}$ diagnosis. The success of alternative models of care in adult populations ${ }^{18}$ calls for an equivalent paediatric focus to both decrease the demand on paediatric EDs and optimise the care provided to a vulnerable patient cohort.

Our data show a range of different medication approaches, where either a single agent, or a combination of oral and/or intramuscular agents were used to chemically restrain children and adolescents. To date, there are no randomised controlled trials (RCTs) studying the best psychotropic management of $A B D$ in the PED environment ${ }^{20}$. In adults, there are multiple high-quality studies identifying and comparing different agents used to manage $A B D$ in the $E D$ setting ${ }^{21}$. The most frequently administered medication (oral 
olanzapine) in our setting has been reported as safe for acute agitation in the PED ${ }^{22}$ and has been shown to be efficacious in adult RCTs ${ }^{21}$. Paediatric RCTs will need to be adequately powered and multicenter to ensure generalisability in the Australian ED setting.

\section{LIMITATIONS}

As a retrospective single centre study there are limitations to the data; however, we tried to optimise data collection by following recommended guidance including the use of trained abstractors, the use of a detailed protocol and data dictionary and intermittent audits $^{12}$. While administrative data and medication use was recorded with high accuracy within the EMR, other data depended on the accuracy and completeness of the recording by the clinicians concerned. The use of ICD 10 diagnostic coding, with its inherent issues of coding accuracy and variability of use among clinicians, to identify participants, may have missed eligible participants with a MH diagnosis. We excluded patients $<7$ years of age as they likely did not present with typical $\mathrm{MH}$ related presentations and often did not have a psychiatric diagnosis. We also excluded drug and/or alcohol affected adolescents if they presented after risk taking behaviours with no $\mathrm{MH}$ diagnosis.

\section{CONCLUSIONS}

Children and adolescents with severe $\mathrm{ABD}$ differ from other $\mathrm{MH}$ presentations and often require physical and/or chemical restraint. While the focus should be on nonpharmacological approaches to de-escalation that are appropriate for the patient's age and

This article is protected by copyright. All rights reserved. 
diagnosis, the multiple medication approaches used in $\mathrm{MH}$ crisis situations calls for adequately powered medication trials to be conducted to provide evidence for their optimal use in the PED. Efforts are required to better understand reasons for repeat presentations where restrictive intervention are required; this group of patients may be amenable to anticipatory management plans and would benefit from a collaborative approach with prehospital services.

This article is protected by copyright. All rights reserved. 


\section{REFERENCES}

1. Hiscock H, Neely RJ, Lei S, Freed G. Paediatric mental health presentations to emergency departments, Victoria, 2008-15. Med J Aust. 2018; 208: 343-348.

2. Tran QN, Lambeth LG, Sanderson K et al. Trends of emergency department presentations with a mental health diagnosis by age, Australia, 2004-05 to 2016-17: A secondary data analysis. Emerg Med Australas. 2019; DOI: 10.1111/17426723.13323.

3. Hoffman JA, Stack AM, Monuteaux MC, Levin R, Lee LK. Factors associated with boarding and length of stay for pediatric mental health emergency visits. Am J Emerg Med. 2018; [Cited 17 Oct 2019]. Available from URL:

http://doi.org/10.1016/i.ajem.2018.12.041

4. Oliver M, Adonopulos AA Haber PS et al. Impact of acutely behavioural disturbed patients in the emergency department: A prospective observational study. Emerg Med Australas. 2018; DOI: 10.1111/1742-6723.13173.

5. Knott J, Gerdtz M, Dobson S et al. Restrictive Interventions in Victorian Emergency Departments: A Review of Current Clinical Practice. Victoria State Government. 2019. Available from URL:

https://www2.health.vic.gov.au/about/publications/researchandreports/restrictiveinterventions-emergency-departments-review

6. Hopper SM, Babl FE, Stewart CE, Woo JW. Aggression management in a children's hospital setting. Med J Aust. 2012: 196: 198-201.

7. The Royal Children's Hospital, Melbourne. Division of Medicine: Mental Health. [Cited 17 Oct 2019]. Available from URL: https://www.rch.org.au/mental-health/

8. Victoria State Government. Mental Health Act, Stat. 14-026. Victorian Legislation and Parliamentary Documents. 2014; [Cited 17 Oct 2019]. Available from URL: http://legislation.vic.gov.au

9. Australian Bureau of Statistics. Victoria: Region Data Summary. [Updated July 2019; Cited 25 Oct 2019]. Available from URL: https://itt.abs.gov.au/itt/r.jsp?RegionSummary\&region=2\&dataset=ABS REGIONAL ASGS2016\&geoconcept=ASGS 2016\&measure=MEASURE\&datasetASGS=ABS REGIO

This article is protected by copyright. All rights reserved. 
NAL ASGS2016\&datasetLGA=ABS REGIONAL LGA2017\&regionLGA=LGA 2017\&regi onASGS=ASGS 2016

10. The Royal Children's Hospital, Melbourne. The Royal Children's Hospital Emergency Management Manual (Part 8). [Updated Mar 2015; cited 21 Oct 2019] Available from URL:

https://www.rch.org.au/uploadedFiles/Main/Content/emergencyprocedures/codegrey.pdf

11. The Royal Children's Hospital, Melbourne. Acute behavioural disturbance: code grey. Clinical Practice Guidelines. [Updated Jul 2017; cited 17 Oct 2019]. Available from URL:

https://www.rch.org.au/clinicalguide/guideline index/acute behavioural disturban ce code grey/

12. Kaji A, Schriger D, Green S. Looking Through the Retrospectoscope: Reducing Bias in Emergency Medicine Chart Review Studies. Ann Emerg Med. 2014; 64: 292-298.

13. Australasian College for Emergency Medicine. Guidelines on the implementation of the Australasian Triage Scale in emergency departments. [Uptdated Jul 2016; cited 17 Oct 2019]. Available from URL: https://acem.org.au/getmedia/51dc74f7-9ffo42ce-872a-0437f3db640a/G24 04 Guidelines on Implementation of ATS Jul16.aspx

14. National Institute for Health and Care Excellence. Violence and aggression: shortterm management in mental health, health and community settings. National Institute for Health and Care Excellence guidelines, 2015. [Updated May 2015; cited 17 Oct 2019]. Available from URL: https://www.nice.org.uk/guidance/ng10

15. The Royal Children's Hospital, Melbourne. Restricive Interventions - Physical and Mechanical restraint. Policies and Procedures. [Updated Jun 2018; cited 14 Feb 2020]. Available from URL:

https://www.rch.org.au/policy/policies/restrictive interventions physical mechanic al restraint/

16. Henderson C, Flood C, Leese M et al. Effect of joint crisis plans on use of compulsory treatment in psychiatry: single blind randomised controlled trial. BMJ; 2004 doi:10.1136/bmj.38155.585046.63.

17. Department of Health and Human Services. Police, Ambulance and Clinical Early Response (PACER) Evaluation, Final Report. The Allen Consulting Group, 2012. [Cited 17 Oct 2019]. Available from URL:

This article is protected by copyright. All rights reserved. 
https://www2.health.vic.gov.au/about/publications/researchandreports/PoliceAmbulance-and-Clinical-Early-Response-PACER-Evaluation-Report

18. Department of Health and Human Services. Victoria's Mental Health Services Annual Report 2017-18. Victoria: Department of Health and Human Services, 2018. [Cited 17 Oct 2019]. Available from URL: www.mentalhealthplan.vic.gov.au

19. Braitberg G, Gerdtz M, Harding S, Pincus S, Thompson M, Knott J. Behavioural assessment unit improves outcomes for patients with complex psychosocial needs. Emerg Med Australas. 2018; 30: 353-358.

20. Gerson R, Malas N, Mroczkowski MM. Crisis in the Emergency Department: The Evaluation and Management of Acute Agitation in Children and Adolescents. Child Adolesc Psychiatr Clin N Am. 2018; 27: 367-368.

21. Taylor DM, Yap CYL, Knott JC et al. Midazolam-Droperidol, Droperidol, or Olanzapine for Acute Agitation: A Randomized Clinical Trial. Ann Emerg Med. 2017; 69: 318326.e1

22. Cole JB, Strobel AM, Klein LR, Blanchard SR, Nahum RH, Martel ML. The use, safety, and efficacy of olanzapine in a pediatric emergency department over a 10-year period. Acad Emerg Med. 2017; 24: S210-S211.

This article is protected by copyright. All rights reserved. 


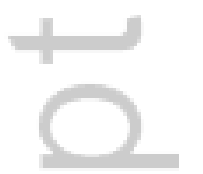

This article is protected by copyright. All rights reserved. 
Figure 1: Flowchart identifying mental health presentations associated with Code Grey event

Table 1: Demographics and length of stay variables of total mental health presentations and Code Grey group

$\dagger$ - length of stay

$\ddagger$ - hours

$\S$ - against medical advice

I - emergency department short stay unit

Table 2: Presentation related variables of Code Grey group $(n=141)$

$\dagger$ - department of human services

$\ddagger$ - outpatient department

$\S$ - general practitioner

Table 3: Code Grey group outcomes $(n=141)$

$\dagger-$ mins

$\ddagger-$ hours

$\S$ - per oral

9 - intramuscular

Table 4: Emergency clinician and mental health clinician diagnoses of Code Grey group $(n=141)$

Table 5: Pre-existing mental health diagnosis in Code Grey group $(n=141)$ 


\begin{tabular}{|c|c|c|c|c|c|c|c|c|}
\hline \multirow[t]{2}{*}{ Demographics } & \multicolumn{2}{|c|}{$\begin{array}{c}\text { Total mental } \\
\text { health } \\
\text { presentations } \\
\text { (1695) }\end{array}$} & \multicolumn{2}{|c|}{$\begin{array}{l}\text { Code Grey } \\
\text { group } \\
(n=141)\end{array}$} & \multicolumn{2}{|c|}{$\begin{array}{l}\text { Non Code Grey } \\
\text { group }(n=1554)\end{array}$} & \multicolumn{2}{|c|}{$\begin{array}{c}\text { Comparison of Code Grey } \\
\text { group to non-Code Grey } \\
\text { group }\end{array}$} \\
\hline & $\mathbf{n}$ & $\begin{array}{c}\% \\
\text { total }\end{array}$ & $\mathbf{n}$ & $\begin{array}{c}\% \\
\text { total } \\
\end{array}$ & $\mathbf{n}$ & $\%$ total & $\begin{array}{c}\text { Variable } \\
\text { compared }\end{array}$ & OR $(95 \% \mathrm{CI})$ \\
\hline \multicolumn{9}{|l|}{ Sex } \\
\hline Female & 1132 & 66.8 & $\begin{array}{c}10 \\
5\end{array}$ & 74.5 & 1027 & 66.1 & $F: M$ & $1.5(1.0-2.2)$ \\
\hline Male & 563 & 33.1 & 36 & 25.5 & 527 & 33.8 & & \\
\hline \multicolumn{9}{|l|}{ Age } \\
\hline $7-12$ & 409 & 24.1 & 47 & 33.3 & 362 & 23.3 & $7-12: 13-17$ & $1.6(1.1-2.4)$ \\
\hline $13-17$ & 1286 & 75.9 & 94 & 66.7 & 1192 & 76.7 & & \\
\hline \multicolumn{9}{|l|}{ Category } \\
\hline 1 & 24 & 1.4 & 20 & 14.2 & 4 & 0.3 & $\begin{array}{l}\text { Cat1\&2: } \\
\text { Cat3-5 }\end{array}$ & $\begin{array}{c}12.6(8.3- \\
19.0)\end{array}$ \\
\hline 2 & 100 & 5.9 & 33 & 23.4 & 67 & 4.3 & & \\
\hline 3 & 1120 & 66.1 & 82 & 58.2 & 1038 & 66.8 & & \\
\hline 4 & 423 & 25.0 & 5 & 3.6 & 418 & 0.3 & & \\
\hline 5 & 28 & 1.7 & 1 & 0.7 & 27 & 1.7 & & \\
\hline \multirow{3}{*}{$\begin{array}{l}\text { Los } † \\
<4 \text { hrs } \ddagger\end{array}$} & & & & & & & & \\
\hline & & & & & & & $>12$ & $8.2(5.1-$ \\
\hline & 706 & 41.7 & 43 & 30.5 & 663 & 42.7 & $\begin{array}{l}\text { hours: } \\
<12 \text { hours }\end{array}$ & 13.1) \\
\hline$>4-6 \mathrm{hrs}$ & 563 & 33.2 & 29 & 20.6 & 534 & 34.4 & & \\
\hline$>6-8 \mathrm{hrs}$ & 229 & 13.5 & 19 & 13.5 & 210 & 13.5 & & \\
\hline$>8-10 \mathrm{hrs}$ & 70 & 4.1 & 12 & 8.5 & 58 & 3.7 & & \\
\hline$>10-12 \mathrm{hrs}$ & 35 & 2.1 & 4 & 2.8 & 31 & 2.0 & & \\
\hline$>12$ hrs & 92 & 5.4 & 34 & 24.1 & 58 & 3.7 & & \\
\hline \multicolumn{9}{|l|}{ Disposition } \\
\hline Discharged & 1355 & 79.9 & 99 & 70.2 & 1256 & 80.8 & $\begin{array}{l}\text { Admitted: } \\
\text { Discharged }\end{array}$ & $2.0(1.4-3.0)$ \\
\hline Admitted & 304 & 17.9 & 41 & 29.1 & 263 & 16.9 & & \\
\hline Left AMA§ & 13 & 0.8 & 1 & 0.7 & 12 & 0.8 & & \\
\hline ED SSUף & 21 & 1.2 & 0 & 0 & 21 & 1.6 & & \\
\hline $\begin{array}{l}\text { Left without } \\
\text { treatment } \\
\text { Arrival day }\end{array}$ & 2 & 0.1 & 0 & 0 & 2 & 0.1 & & \\
\hline Weekday & 1314 & 77.5 & $\begin{array}{c}10 \\
4\end{array}$ & 73.8 & 1210 & 77.8 & $\begin{array}{l}\text { Weekday: } \\
\text { Weekend }\end{array}$ & $1.3(0.8-1.9)$ \\
\hline $\begin{array}{l}\text { Weekend } \\
\text { Arrival time }\end{array}$ & 381 & 22.5 & 37 & 26.3 & 344 & 22.1 & & \\
\hline 0000-0759 & 160 & 9.5 & 20 & 14.2 & 140 & 9.1 & & \\
\hline 0800-1559 & 647 & 38.2 & 49 & 34.7 & 598 & 38.4 & & \\
\hline $1600-2359$ & 888 & 52.4 & 72 & 51 & 816 & 52.5 & & \\
\hline After hours & & & & & & & After & $1.3(0.9-1.8)$ \\
\hline$(1700-0759)$ & 931 & 54.9 & 85 & 60.3 & 846 & 54.4 & $\begin{array}{l}\text { hours: } \\
\text { Business } \\
\text { hours }\end{array}$ & \\
\hline $\begin{array}{l}\text { In hours } \\
(0800-1659)\end{array}$ & 764 & 45.1 & 56 & 39.7 & 708 & 45.6 & & \\
\hline
\end{tabular}

This article is protected by copyright. All rights reserved. 


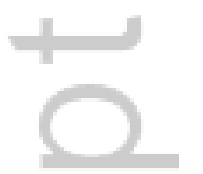

This article is protected by copyright. All rights reserved. 


\begin{tabular}{|c|c|c|}
\hline \multirow[b]{2}{*}{ Means of arrival } & $\mathbf{n}$ & $\%$ \\
\hline & & \\
\hline Police & 72 & 51.1 \\
\hline Ambulance & 36 & 25.5 \\
\hline $\begin{array}{l}\text { Private car / self / public } \\
\text { transport }\end{array}$ & 33 & 23,4 \\
\hline Sectioned & & 23.4 \\
\hline No & 84 & 59.6 \\
\hline Yes & 54 & 38.3 \\
\hline Unknown & 3 & 2.1 \\
\hline Guardianship & & \\
\hline Parent & 97 & 68.8 \\
\hline DHS† & 36 & 25.5 \\
\hline Other family & 4 & 2.8 \\
\hline Police / Juvenile system & 3 & 2.1 \\
\hline Friend & 1 & 0.7 \\
\hline Attended with & & \\
\hline Parent & 83 & 58.9 \\
\hline $\begin{array}{l}\text { Residential care / social } \\
\text { worker }\end{array}$ & 24 & 17.0 \\
\hline Alone & 19 & 13.5 \\
\hline Friend & 7 & 5.0 \\
\hline DHS worker & 4 & 2.8 \\
\hline Other & 2 & 1.4 \\
\hline Community psychiatric & & \\
\hline liaison & 1 & 0.7 \\
\hline Teacher & 1 & 0.7 \\
\hline $\begin{array}{l}\text { Prior psychiatric / } \\
\text { community care }\end{array}$ & & \\
\hline Yes & 130 & 92.2 \\
\hline No & 11 & 7.8 \\
\hline Past psychiatric diagnosis & & \\
\hline Yes & 135 & 95.7 \\
\hline No & 6 & 4.3 \\
\hline Disposition from ED & & \\
\hline Home & 72 & 51.1 \\
\hline Admitted RCH & 38 & 27.0 \\
\hline Admitted to another facility & 11 & 7.8 \\
\hline Residential care & 13 & 9.2 \\
\hline Police custody & 3 & 2.1 \\
\hline DHS & 3 & 2.1 \\
\hline Absconded & 1 & 0.7 \\
\hline Discharged with & & \\
\hline Parent & 81 & $\mathbf{5 7 . 5}$ \\
\hline $\begin{array}{l}\text { Residential carer / social } \\
\text { worker }\end{array}$ & 33 & 23.4 \\
\hline DHS worker & 7 & 5.0 \\
\hline Other & 7 & 5.0 \\
\hline Police & 6 & 4.3 \\
\hline Unknown & $\mathbf{5}$ & 3.6 \\
\hline Alone & 1 & 0.7 \\
\hline Friend & 1 & 0.7 \\
\hline
\end{tabular}

This article is protected by copyright. All rights reserved. 


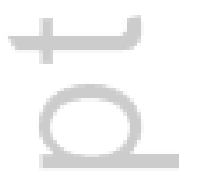

This article is protected by copyright. All rights reserved. 


\begin{tabular}{|c|c|c|}
\hline \multirow{2}{*}{$\begin{array}{l}\text { Outcomes } \\
\text { Timing of first Code } \\
\text { Grey post arrival to } \\
\text { ED }\end{array}$} & \multicolumn{2}{|c|}{ Code Grey group } \\
\hline & $\mathbf{n}$ & $\%$ total \\
\hline $0-30$ mins $\dagger$ & 73 & 51.8 \\
\hline 31 mins -2 hrs $\ddagger$ & 31 & 22.0 \\
\hline$>2 \mathrm{hrs}-4 \mathrm{hrs}$ & 18 & 12.8 \\
\hline$>4 \mathrm{hrs}-6 \mathrm{hrs}$ & 7 & 5.0 \\
\hline $\begin{array}{l}>6 \mathrm{hrs} \\
\text { Code Grey time of } \\
\text { day }\end{array}$ & 12 & 8.5 \\
\hline 00:00-07:59 & 20 & 14.2 \\
\hline 08:00-15:59 & 47 & 33.3 \\
\hline $16: 00-23: 59$ & 74 & 52.5 \\
\hline \multicolumn{3}{|l|}{$\begin{array}{l}\text { Number of Code } \\
\text { Greys during ED } \\
\text { presentation }\end{array}$} \\
\hline 1 & 98 & 69.5 \\
\hline 2 & 30 & 21.3 \\
\hline 3 & 8 & 5.7 \\
\hline 4 & 3 & 2.1 \\
\hline 5 & 2 & 1.4 \\
\hline \multicolumn{3}{|l|}{ Restraint } \\
\hline Mechanical & 45 & 31.9 \\
\hline Physical & 27 & 19.2 \\
\hline Shepherding & 27 & 19.2 \\
\hline Presence & 20 & 14.2 \\
\hline None & 22 & 15.6 \\
\hline \multicolumn{3}{|l|}{ Medication } \\
\hline No & 88 & 62.4 \\
\hline Yes & 53 & 37.6 \\
\hline \multicolumn{3}{|l|}{ Medication type } \\
\hline POS & 31 & 58.5 \\
\hline \multicolumn{3}{|l|}{ Seclusion } \\
\hline No & 98 & 69.5 \\
\hline Yes & 43 & 30.5 \\
\hline Medications & $\begin{array}{c}\text { n (times } \\
\text { administered) }\end{array}$ & $\begin{array}{c}\% \text { (of total } \\
\text { medications given) }\end{array}$ \\
\hline Olanzapine PO & 22 & 27.9 \\
\hline Droperidol IM & 14 & 17.7 \\
\hline Olanzapine IM & 12 & 15.2 \\
\hline Diazepam PO & 11 & 13.9 \\
\hline Midazolam IM & 9 & 11.4 \\
\hline Lorazepam PO & 7 & 8.9 \\
\hline Diazepam IM & 2 & 2.5 \\
\hline Midazolam PO & 2 & 2.5 \\
\hline
\end{tabular}

This article is protected by copyright. All rights reserved. 


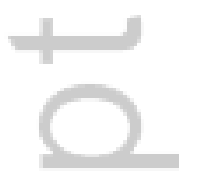

This article is protected by copyright. All rights reserved. 


\begin{tabular}{|c|c|c|c|c|}
\hline \multirow[t]{2}{*}{ Diagnosis } & \multicolumn{2}{|c|}{$\begin{array}{l}\text { Emergency } \\
\text { clinician } \\
\text { diagnosis }\end{array}$} & \multicolumn{2}{|c|}{$\begin{array}{c}\text { Mental health } \\
\text { clinician diagnosis }\end{array}$} \\
\hline & $\mathbf{n}$ & $\%$ total & $\mathbf{n}$ & $\%$ total \\
\hline $\begin{array}{l}\text { Acute behavioural } \\
\text { disturbance }\end{array}$ & 58 & 41.1 & 47 & 33.3 \\
\hline Suicidal ideation & 39 & 27.7 & 38 & 27.0 \\
\hline Self-harm & 14 & 9.9 & 11 & 7.8 \\
\hline Drug overdose & 13 & 9.2 & 4 & 3.6 \\
\hline Anxiety & 4 & 2.8 & 6 & 4.3 \\
\hline Acute psychosis & 3 & 2.1 & 2 & 1.4 \\
\hline Anorexia nervosa & 3 & 2.1 & 3 & 2.1 \\
\hline $\begin{array}{l}\text { Affective bipolar } \\
\text { disorder }\end{array}$ & 2 & 1.4 & 2 & 1.4 \\
\hline Depression & 2 & 1.4 & 2 & 1.4 \\
\hline Drug withdrawal & 1 & 0.7 & 1 & 0.0 \\
\hline Suicide attempt & 1 & 0.7 & 1 & 0.7 \\
\hline Adjustment disorder & 0 & 0.0 & 1 & 0.7 \\
\hline $\begin{array}{l}\text { Borderline personality } \\
\text { disorder }\end{array}$ & 0 & 0.0 & 1 & 0.7 \\
\hline Crisis presentation & 0 & 0.0 & 6 & 4.3 \\
\hline $\begin{array}{l}\text { Emotional } \\
\text { dysregulation }\end{array}$ & 0 & 0.0 & 5 & 3.6 \\
\hline $\begin{array}{l}\text { Homicidal and suicidal } \\
\text { ideation }\end{array}$ & 0 & 0.0 & 1 & 0.7 \\
\hline Nil & 0 & 0.0 & 9 & 6.4 \\
\hline Relational disorder & 0 & 0.0 & 1 & 0.7 \\
\hline Physical injury & 1 & 0.7 & 0 & 0.0 \\
\hline
\end{tabular}

This article is protected by copyright. All rights reserved. 


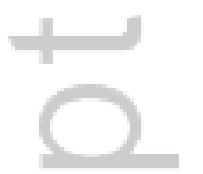

This article is protected by copyright. All rights reserved. 


\begin{tabular}{|c|c|c|}
\hline \multirow[t]{2}{*}{ Diagnosis } & \multicolumn{2}{|c|}{$\begin{array}{l}\text { Pre-existing } \\
\text { mental health } \\
\text { diagnosis }\end{array}$} \\
\hline & $\mathbf{n}$ & $\begin{array}{c}\% \\
\text { total }\end{array}$ \\
\hline Nil & 35 & 24.8 \\
\hline $\begin{array}{l}\text { Autism spectrum } \\
\text { disorder }\end{array}$ & 24 & 17.0 \\
\hline Suicidal ideation & 20 & 14.2 \\
\hline Depression & 16 & 11.4 \\
\hline Anxiety & 9 & 6.4 \\
\hline Self-harm & 7 & 5.0 \\
\hline $\begin{array}{l}\text { Emotional } \\
\text { dysregulation }\end{array}$ & 7 & 5.0 \\
\hline $\begin{array}{l}\text { Borderline personality } \\
\text { disorder }\end{array}$ & 5 & 3.6 \\
\hline Drug overdose & 3 & 2.1 \\
\hline $\begin{array}{l}\text { Anorexia nervosa } \\
\text { Oppositional defiance }\end{array}$ & 3 & 2.1 \\
\hline $\begin{array}{l}\text { disorder } \\
\text { Attention deficit }\end{array}$ & 3 & 2.1 \\
\hline hyperactivity disorder & 3 & 2.1 \\
\hline $\begin{array}{l}\text { Intellectual disability } \\
\text { Schizophrenia / } \\
\text { schizoaffective }\end{array}$ & 3 & 2.1 \\
\hline $\begin{array}{l}\text { disorder } \\
\text { Obsessive compulsive }\end{array}$ & 2 & 1.4 \\
\hline disorder & 1 & 0.7 \\
\hline
\end{tabular}

This article is protected by copyright. All rights reserved. 


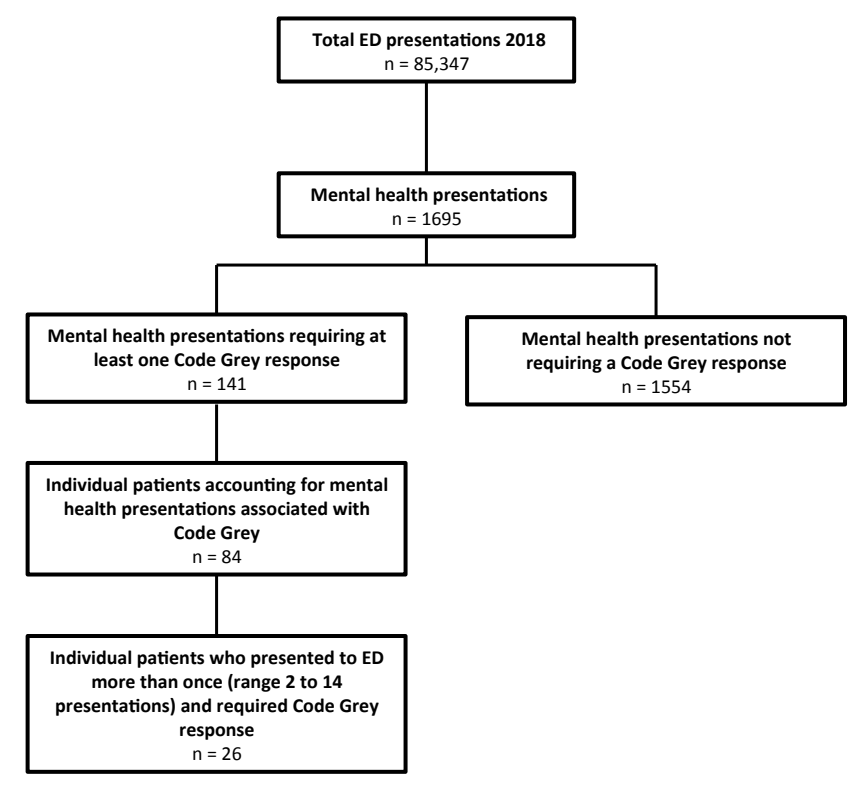

This article is protected by copyright. All rights reserved. 


\begin{tabular}{|c|c|c|c|c|c|c|c|c|}
\hline \multirow[t]{2}{*}{ Demographics } & \multicolumn{2}{|c|}{$\begin{array}{c}\text { Total mental } \\
\text { health } \\
\text { presentations } \\
\quad(1695)\end{array}$} & \multicolumn{2}{|c|}{$\begin{array}{l}\text { Code Grey } \\
\text { group } \\
(n=141)\end{array}$} & \multicolumn{2}{|c|}{$\begin{array}{l}\text { Non Code Grey } \\
\text { group }(n=1554)\end{array}$} & \multicolumn{2}{|c|}{$\begin{array}{l}\text { Comparison of Code Grey } \\
\text { group to non-Code Grey } \\
\text { group }\end{array}$} \\
\hline & n & $\begin{array}{c}\% \\
\text { total }\end{array}$ & $\mathbf{n}$ & $\begin{array}{c}\% \\
\text { total }\end{array}$ & $\mathbf{n}$ & $\%$ total & $\begin{array}{l}\text { Variable } \\
\text { compared }\end{array}$ & OR (95\% CI) \\
\hline $\begin{array}{l}\text { Sex } \\
\text { Female }\end{array}$ & 1132 & 66.8 & $\begin{array}{c}10 \\
5\end{array}$ & 74.5 & 1027 & 66.1 & F:M & $1.5(1.0-2.2)$ \\
\hline $\begin{array}{l}\text { Male } \\
\text { Age }\end{array}$ & 563 & 33.1 & 36 & 25.5 & 527 & 33.8 & & \\
\hline $7-12$ & 409 & 24.1 & 47 & 33.3 & 362 & 23.3 & $7-12: 13-17$ & $1.6(1.1-2.4)$ \\
\hline $\begin{array}{l}13-17 \\
\text { Category }\end{array}$ & 1286 & 75.9 & 94 & 66.7 & 1192 & 76.7 & & \\
\hline 1 & 24 & 1.4 & 20 & 14.2 & 4 & 0.3 & $\begin{array}{l}\text { Cat1\&2: } \\
\text { Cat3-5 }\end{array}$ & $\begin{array}{c}12.6(8.3- \\
19.0)\end{array}$ \\
\hline 2 & 100 & 5.9 & 33 & 23.4 & 67 & 4.3 & & \\
\hline 3 & 1120 & 66.1 & 82 & 58.2 & 1038 & 66.8 & & \\
\hline 4 & 423 & 25.0 & 5 & 3.6 & 418 & 0.3 & & \\
\hline 5 & 28 & 1.7 & 1 & 0.7 & 27 & 1.7 & & \\
\hline LOS $†$ & & & & & & & & \\
\hline$<4$ hrsł & 706 & 41.7 & 43 & 30.5 & 663 & 42.7 & $\begin{array}{c}>12 \\
\text { hours: } \\
<12 \text { hours }\end{array}$ & $\begin{array}{l}8.2(5.1- \\
13.1)\end{array}$ \\
\hline$>4-6 \mathrm{hrs}$ & 563 & 33.2 & 29 & 20.6 & 534 & 34.4 & & \\
\hline$>6-8 \mathrm{hrs}$ & 229 & 13.5 & 19 & 13.5 & 210 & 13.5 & & \\
\hline$>8-10 \mathrm{hrs}$ & 70 & 4.1 & 12 & 8.5 & 58 & 3.7 & & \\
\hline$>10-12 \mathrm{hrs}$ & 35 & 2.1 & 4 & 2.8 & 31 & 2.0 & & \\
\hline $\begin{array}{l}>12 \mathrm{hrs} \\
\text { Disposition }\end{array}$ & 92 & 5.4 & 34 & 24.1 & 58 & 3.7 & & \\
\hline Discharged & 1355 & 79.9 & 99 & 70.2 & 1256 & 80.8 & $\begin{array}{l}\text { Admitted: } \\
\text { Discharged }\end{array}$ & $2.0(1.4-3.0)$ \\
\hline Admitted & 304 & 17.9 & 41 & 29.1 & 263 & 16.9 & & \\
\hline Left AMA§ & 13 & 0.8 & 1 & 0.7 & 12 & 0.8 & & \\
\hline ED SSUף & 21 & 1.2 & 0 & 0 & 21 & 1.6 & & \\
\hline $\begin{array}{l}\text { Left without } \\
\text { treatment } \\
\text { Arrival day }\end{array}$ & 2 & 0.1 & 0 & 0 & 2 & 0.1 & & \\
\hline Weekday & 1314 & 77.5 & $\begin{array}{c}10 \\
4\end{array}$ & 73.8 & 1210 & 77.8 & $\begin{array}{l}\text { Weekday: } \\
\text { Weekend }\end{array}$ & $1.3(0.8-1.9)$ \\
\hline $\begin{array}{l}\text { Weekend } \\
\text { Arrival time }\end{array}$ & 381 & 22.5 & 37 & 26.3 & 344 & 22.1 & & \\
\hline 0000-0759 & 160 & 9.5 & 20 & 14.2 & 140 & 9.1 & & \\
\hline 0800-1559 & 647 & 38.2 & 49 & 34.7 & 598 & 38.4 & & \\
\hline $1600-2359$ & 888 & 52.4 & 72 & 51 & 816 & 52.5 & & \\
\hline $\begin{array}{l}\text { After hours } \\
(1700-0759)\end{array}$ & 931 & 54.9 & 85 & 60.3 & 846 & 54.4 & $\begin{array}{l}\text { After } \\
\text { hours: } \\
\text { Business } \\
\text { hours }\end{array}$ & $1.3(0.9-1.8)$ \\
\hline $\begin{array}{l}\text { In hours } \\
(0800-1659)\end{array}$ & 764 & 45.1 & 56 & 39.7 & 708 & 45.6 & & \\
\hline
\end{tabular}

This article is protected by copyright. All rights reserved. 


\begin{tabular}{|c|c|c|}
\hline \multirow[b]{2}{*}{ Means of arrival } & \multirow[t]{2}{*}{$\mathbf{n}$} & \multirow[t]{2}{*}{$\%$} \\
\hline & & \\
\hline Police & 72 & 51.1 \\
\hline Ambulance & 36 & 25.5 \\
\hline $\begin{array}{l}\text { Private car / self / public } \\
\text { transport }\end{array}$ & 33 & 23.4 \\
\hline Sectioned & & \\
\hline No & 84 & 59.6 \\
\hline Yes & 54 & 38.3 \\
\hline Unknown & 3 & 2.1 \\
\hline \multicolumn{3}{|l|}{ Guardianship } \\
\hline Parent & 97 & 68.8 \\
\hline DHS† & 36 & 25.5 \\
\hline Other family & 4 & 2.8 \\
\hline Police / Juvenile system & 3 & 2.1 \\
\hline Friend & 1 & 0.7 \\
\hline \multicolumn{3}{|l|}{ Attended with } \\
\hline Parent & 83 & 58.9 \\
\hline $\begin{array}{l}\text { Residential care / social } \\
\text { worker }\end{array}$ & 24 & 17.0 \\
\hline Alone & 19 & 13.5 \\
\hline Friend & 7 & 5.0 \\
\hline DHS worker & 4 & 2.8 \\
\hline Other & 2 & 1.4 \\
\hline \multicolumn{3}{|l|}{ Community psychiatric } \\
\hline liaison & 1 & 0.7 \\
\hline Teacher & 1 & 0.7 \\
\hline \multicolumn{3}{|l|}{$\begin{array}{l}\text { Prior psychiatric / } \\
\text { community care }\end{array}$} \\
\hline Yes & 130 & 92.2 \\
\hline No & 11 & 7.8 \\
\hline \multicolumn{3}{|l|}{ Past psychiatric diagnosis } \\
\hline Yes & 135 & 95.7 \\
\hline No & 6 & 4.3 \\
\hline \multicolumn{3}{|l|}{ Disposition from ED } \\
\hline Home & 72 & 51.1 \\
\hline Admitted RCH & 38 & 27.0 \\
\hline Admitted to another facility & 11 & 7.8 \\
\hline Residential care & 13 & 9.2 \\
\hline Police custody & 3 & 2.1 \\
\hline DHS & 3 & 2.1 \\
\hline Absconded & 1 & 0.7 \\
\hline \multicolumn{3}{|l|}{ Discharged with } \\
\hline Parent & 81 & 57.5 \\
\hline Residential carer / social & & \\
\hline worker & 33 & 23.4 \\
\hline DHS worker & 7 & 5.0 \\
\hline Other & 7 & 5.0 \\
\hline Police & 6 & 4.3 \\
\hline Unknown & 5 & 3.6 \\
\hline Alone & 1 & 0.7 \\
\hline Friend & 1 & 0.7 \\
\hline
\end{tabular}

This article is protected by copyright. All rights reserved. 
Follow up arrangements

Community psychiatric

services

Hospital Psychiatry OPD $\ddagger$

9.28

Transfer to another unit

Paediatrician

Private Psychiatrist /

Counselor

2.1

None

1.4

Unknown

1.4

GP§

0.7

This article is protected by copyright. All rights reserved. 


\begin{tabular}{|c|c|c|}
\hline Outcomes & Code & y group \\
\hline $\begin{array}{l}\text { Timing of first Code } \\
\text { Grey post arrival to } \\
\text { ED }\end{array}$ & $\mathbf{n}$ & $\%$ total \\
\hline $0-30$ mins $\dagger$ & 73 & 51.8 \\
\hline 31 mins - 2 hrs $\ddagger$ & 31 & 22.0 \\
\hline$>2 \mathrm{hrs}-4 \mathrm{hrs}$ & 18 & 12.8 \\
\hline$>4 \mathrm{hrs}-6 \mathrm{hrs}$ & 7 & 5.0 \\
\hline$>6 \mathrm{hrs}$ & 12 & 8.5 \\
\hline $\begin{array}{l}\text { Code Grey time of } \\
\text { day }\end{array}$ & & \\
\hline 00:00-07:59 & 20 & 14.2 \\
\hline 08:00-15:59 & 47 & 33.3 \\
\hline $16: 00-23: 59$ & 74 & 52.5 \\
\hline $\begin{array}{l}\text { Number of Code } \\
\text { Greys during ED } \\
\text { presentation }\end{array}$ & & \\
\hline 1 & 98 & 69.5 \\
\hline 2 & 30 & 21.3 \\
\hline 3 & 8 & 5.7 \\
\hline 4 & 3 & 2.1 \\
\hline 5 & 2 & 1.4 \\
\hline Restraint & & \\
\hline Mechanical & 45 & 31.9 \\
\hline Physical & 27 & 19.2 \\
\hline Shepherding & 27 & 19.2 \\
\hline Presence & 20 & 14.2 \\
\hline None & 22 & 15.6 \\
\hline Medication & & \\
\hline No & 88 & 62.4 \\
\hline Yes & 53 & 37.6 \\
\hline Medication type & & \\
\hline PO§ & 31 & 58.5 \\
\hline IMף & 22 & 41.5 \\
\hline Seclusion & & \\
\hline No & 98 & 69.5 \\
\hline Yes & 43 & 30.5 \\
\hline Medications & $\begin{array}{c}\mathrm{n} \text { (times } \\
\text { administered) }\end{array}$ & $\begin{array}{c}\% \text { (of total } \\
\text { medications given) }\end{array}$ \\
\hline Olanzapine PO & 22 & 27.9 \\
\hline Droperidol IM & 14 & 17.7 \\
\hline Olanzapine IM & 12 & 15.2 \\
\hline Diazepam PO & 11 & 13.9 \\
\hline Midazolam IM & 9 & 11.4 \\
\hline Lorazepam PO & 7 & 8.9 \\
\hline Diazepam IM & 2 & 2.5 \\
\hline Midazolam PO & 2 & 2.5 \\
\hline
\end{tabular}

This article is protected by copyright. All rights reserved. 


\begin{tabular}{|c|c|c|c|c|}
\hline \multirow[t]{2}{*}{ Diagnosis } & \multicolumn{2}{|c|}{$\begin{array}{l}\text { Emergency } \\
\text { clinician } \\
\text { diagnosis }\end{array}$} & \multicolumn{2}{|c|}{$\begin{array}{l}\text { Mental health } \\
\text { clinician diagnosis }\end{array}$} \\
\hline & $\mathbf{n}$ & $\%$ total & $\mathbf{n}$ & $\%$ total \\
\hline $\begin{array}{l}\text { Acute behavioural } \\
\text { disturbance }\end{array}$ & 58 & 41.1 & 47 & 33.3 \\
\hline Suicidal ideation & 39 & 27.7 & 38 & 27.0 \\
\hline Self-harm & 14 & 9.9 & 11 & 7.8 \\
\hline Drug overdose & 13 & 9.2 & 4 & 3.6 \\
\hline Anxiety & 4 & 2.8 & 6 & 4.3 \\
\hline Acute psychosis & 3 & 2.1 & 2 & 1.4 \\
\hline Anorexia nervosa & 3 & 2.1 & 3 & 2.1 \\
\hline $\begin{array}{l}\text { Affective bipolar } \\
\text { disorder }\end{array}$ & 2 & 1.4 & 2 & 1.4 \\
\hline Depression & 2 & 1.4 & 2 & 1.4 \\
\hline Drug withdrawal & 1 & 0.7 & 1 & 0.0 \\
\hline Suicide attempt & 1 & 0.7 & 1 & 0.7 \\
\hline Adjustment disorder & 0 & 0.0 & 1 & 0.7 \\
\hline $\begin{array}{l}\text { Borderline personality } \\
\text { disorder }\end{array}$ & 0 & 0.0 & 1 & 0.7 \\
\hline Crisis presentation & 0 & 0.0 & 6 & 4.3 \\
\hline $\begin{array}{l}\text { Emotional } \\
\text { dysregulation }\end{array}$ & 0 & 0.0 & 5 & 3.6 \\
\hline $\begin{array}{l}\text { Homicidal and suicidal } \\
\text { ideation }\end{array}$ & 0 & 0.0 & 1 & 0.7 \\
\hline Nil & 0 & 0.0 & 9 & 6.4 \\
\hline Relational disorder & 0 & 0.0 & 1 & 0.7 \\
\hline Physical injury & 1 & 0.7 & 0 & 0.0 \\
\hline
\end{tabular}

This article is protected by copyright. All rights reserved. 


\begin{tabular}{|c|c|c|}
\hline \multirow[t]{3}{*}{ Diagnosis } & \multicolumn{2}{|c|}{$\begin{array}{l}\text { Pre-existing } \\
\text { mental health } \\
\text { diagnosis }\end{array}$} \\
\hline & & $\%$ \\
\hline & $\mathbf{n}$ & total \\
\hline Nil & 35 & 24.8 \\
\hline Autism spectrum & & \\
\hline disorder & 24 & 17.0 \\
\hline Suicidal ideation & 20 & 14.2 \\
\hline Depression & 16 & 11.4 \\
\hline Anxiety & 9 & 6.4 \\
\hline Self-harm & 7 & 5.0 \\
\hline $\begin{array}{l}\text { Emotional } \\
\text { dysregulation }\end{array}$ & 7 & 5.0 \\
\hline $\begin{array}{l}\text { Borderline personality } \\
\text { disorder }\end{array}$ & 5 & 3.6 \\
\hline Drug overdose & 3 & 2.1 \\
\hline Anorexia nervosa & 3 & 2.1 \\
\hline $\begin{array}{l}\text { Oppositional defiance } \\
\text { disorder } \\
\text { Attention deficit }\end{array}$ & 3 & 2.1 \\
\hline hyperactivity disorder & 3 & 2.1 \\
\hline Intellectual disability & 3 & 2.1 \\
\hline $\begin{array}{l}\text { Schizophrenia / } \\
\text { schizoaffective }\end{array}$ & & \\
\hline $\begin{array}{l}\text { disorder } \\
\text { Obsessive compulsive }\end{array}$ & 2 & 1.4 \\
\hline disorder & 1 & 0.7 \\
\hline
\end{tabular}

This article is protected by copyright. All rights reserved. 


\section{University Library}

\section{- M M N E R VA A gateway to Melbourne's research publications}

Minerva Access is the Institutional Repository of The University of Melbourne

Author/s:

Carison, A;Babl, FE;Hill, A;O'Donnell, SM

Title:

Children and adolescents with severe acute behavioural disturbance in the emergency department

Date:

2020-04-28

\section{Citation:}

Carison, A., Babl, F. E., Hill, A. \& O'Donnell, S. M. (2020). Children and adolescents with severe acute behavioural disturbance in the emergency department. EMERGENCY MEDICINE AUSTRALASIA, 32 (5), pp.747-755. https://doi.org/10.1111/1742-6723.13515.

Persistent Link:

http://hdl.handle.net/11343/275689 